\title{
Determination of genetic variations by using mitochondrial DNA cyt b sequences in populations of Carasobarbus luteus (Cyprinidae)
}

\author{
Arif PARMAKSIZ \\ Cite this article as: \\ Parmaksiz, A. (2021). Determination of genetic variations by using mitochondrial DNA cyt b sequences in populations of Carasobarbus luteus (Cypri- \\ nidae). Aquatic Research, 4(4), 313-320. https://doi.org/10.3153/AR21026
}

Harran University, Faculty of Science and Art, Department of Biology, 63100, Şanlıurfa, Turkey

ORCID IDs of the author(s): A.P. 0000-0003-0321-8198

Submitted: 01.02 .2021

Revision requested: 06.03 .2021

Last revision received: 16.03 .2021

Accepted: 16.03.2021

Published online: 19.05 .2021

Correspondence:

Arif PARMAKSIZ

E-mail: aprmksz@gmail.com

\begin{abstract}
As the human population increases, freshwater fish has become an important alternative source of protein to meet the need of protein. Especially numerous fish species from the family Cyprinidae are consumed by the people. Among these fish, Carasobarbus luteus (Heckel, 1843) is also one of the most preferred species thanks to its edible flesh as well as its low price. Since it is economically important, there has been the pressure of overfishing and invasive species on the populations of this species, resulting in decrease of the sources day by day. Management and conservation of the species have importance therefore it is need to know its genetic variations in the first place. The present study analyzed sequences of mtDNA cyt b locus and established the genetic variability following the collection of 65 individuals from five different localities in diverse river systems where $C$. luteus populations naturally inhabit. Sequence analysis revealed 13 polymorphic sites and 5 haplotypes. Birecik was the locality with the highest value in terms of both haplotype diversity and nucleotide diversity, Diyarbakır was the one with the lowest value. Tajima's D and Fu's Fs values were found to be statistically insignificant for all the localities. Population genetic diversity of this fish species was found to be low in terms of mtDNA cyt b marker. It is recommended to take measures to stop the loss of genetic diversity and to start conservation studies.
\end{abstract}

Keywords: Carasobarbus luteus, cyt b haplotypes, Genetic diversity, Euphrates River, Tigris River

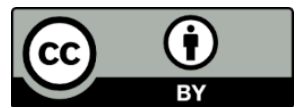

(C) 2021 The Author(s) 


\section{Introduction}

Development of urbanization and agriculture have a gradually increasing impact on both natural habitats and species, decrease the quantity of habitats which are appropriate for the wildlife species (Goudie, 2018; Zhang et. al., 2020). Destruction or change of habitats may lead to decline in the diversity of species and even to extinction of certain species. It has been estimated that genetic diversity has been decreasing faster than diversity of species under increasing number of threats, however its spatial distribution has not been adequately documented on a global scale yet (Manel et. al.,2020). Genetic diversity directly reflects the ability of species or population to adapt in environmental factors of alien habitats (Frankham et al., 2002; Spielman et al., 2004).

Populations in aquatic habitats are frequently under threat because of human pressure such as pollution, harvesting, fishing, alien species, tourism, and urban development (Cognetti and Maltagliati, 2000). Carasobarbus luteus which is the subject of our study and a species exposed to those threats is called Bizir or Common carp by the local people. C. luteus is a species from Cyprinidae family which is widely distributed in Euphrates, Tigris rivers, natural and artificial lakes in Mesopotamia (Kuru, 1979; Ünlü, 1991; Gökçek and Akyurt, 2008; Coad, 2010). Different studies have been done for this species, some of which are; investigation of reproductive organs and tissues (Rahemo and Al-Shatter, 2012), spermatologic characteristics (Aral et al., 2014), content of digestive system (Çelik and Saler, 2016), reproductive biology (Bilici et al., 2017), parasite studies (Mansoor et al., 2020).

Particularly fishing and dominant status of invasive species are the factors threatening this species most, and lead to decrease in the number of individuals in populations day by day. Decreased individuals in natural populations may result in the extinction of unique genotypes that are not found anywhere else (Parmaksiz, 2020). When a genetic data is lost, it is almost impossible to bring it back (Parmaksiz, 2020). Therefore, measurements are needed to stop loss of genetic data and to protect future of this species should be taken. For an effective conservation program, firstly there should be reliable genetic data. Analysis of population genetics is a useful tool to acquire knowledge about a species in order to protect it (Ryman, 1991; Ward, 2000). Mitochondrial DNA markers have been utilized in genetic studies on various species (Xia et al., 2016). As compared to nuclear DNA markers, mitochondrial DNA markers are preferred thanks to their unique characteristics such as maternal inheritance, lacking of fast evaluation and recombination. Diverse mtDNA gene sequences can be used to determine the variation in fish species (Saraswat et. al.,2014). Cyt b gene which is an effective molecular marker and has been used to analyze genetic data of several species (Maltagliati et al., 2010; Li et al., 2013; Deng et al., 2014). Variation in mtDNA cyt b gene is utilized for studies for genetic analysis of fish populations from order Cypriniformes (Fayazi et al., 2006). mtDNA cyt-b gene locus has been appeared to be a multipotent genetic marker that can be especially used for genetic variation analysis of fish (Saraswat et. al., 2014).

The goal of the present survey is to identify genetic variation in populations of $C$. luteus naturally inhabiting in river systems of Euphrates and Tigris via gene sequence analysis of mtDNA cyt b locus.

\section{Material and Methods}

65 fish samples used as the material of the present study were collected from 5 localities belonging to 2 different river systems. The map of these localities is given in Figure 1. Fish samples were included in the study by random sampling from fishes caught by fishermen at different times. Previous field surveys were utilized for selection of the localities where fish samples would be collected. Accordingly; localities on the river systems of Euphrates and Tigris were concluded as appropriate considering the number of samples in populations, convenience of the land conditions, presence of fishermen in adequate number, and closer distance to city center.

These samples which were purchased from fishermen were kept inside an ice bucket to transfer Zoology Laboratory of Harran University, Faculty of Science-Literature, Department of Biology. Following the identification of species, muscle tissue dissected from the samples was transferred into microcentrifuge tubes with a content of $90 \%$ of ethanol and kept at $-20 \mathrm{C}$ until DNA was extracted.

Total DNA was isolated from muscle tissue using GeneJET Genomic DNA Purification Kit (Thermo Scientific). To check the presence of DNA after the protocol, DNA samples from all individuals were run placing in the wells of $1 \%$ of agarose gel with addition of SYBR Green, monitorized under UV light device (Smart View Pro Imager System, Major Science). 


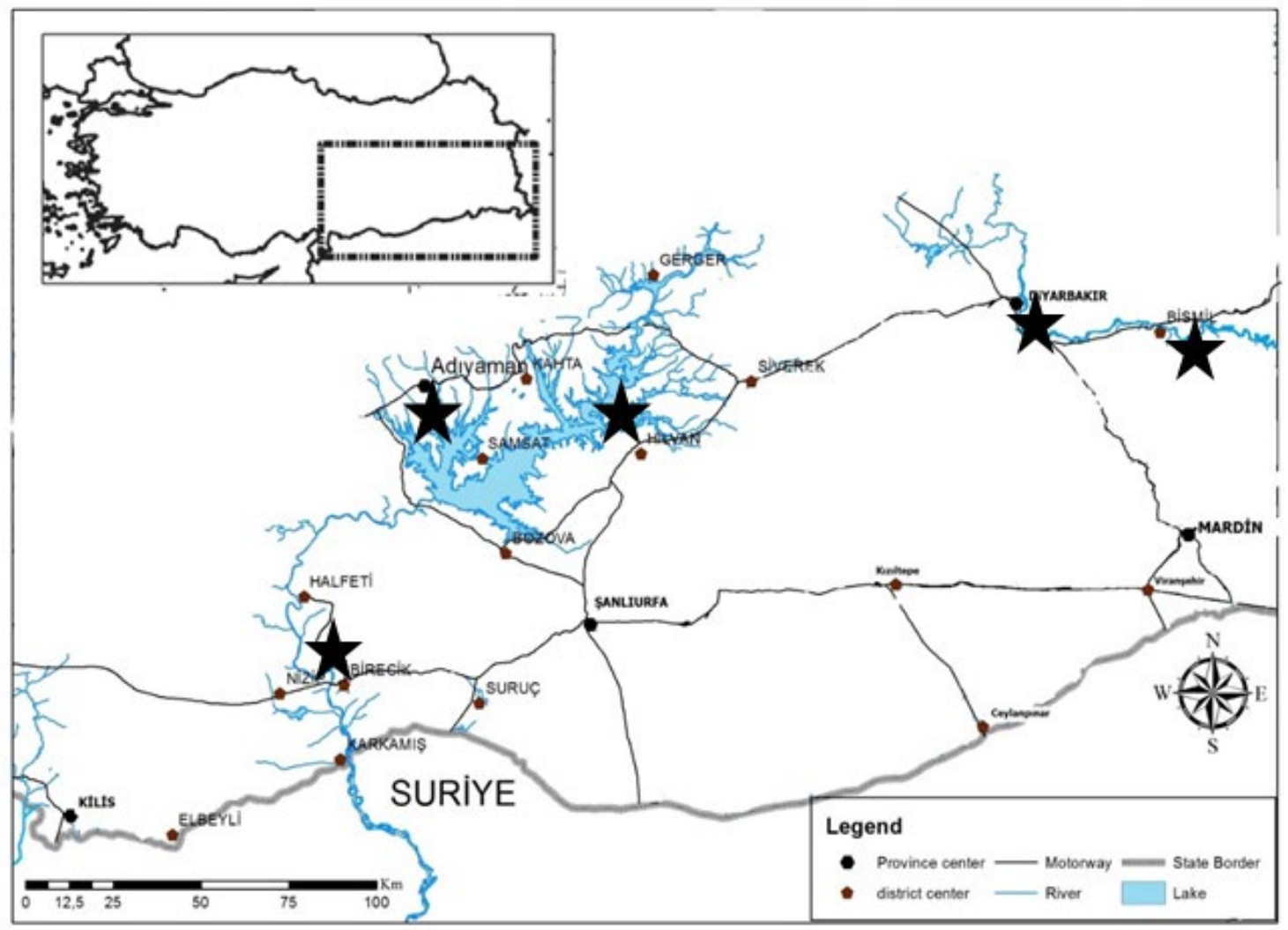

Figure 1. The map indicating the localities where $C$. luteus samples were collected

Target mtDNA cyt $b$ gene locus was amplified by Polymerase Chain Reaction (PCR), the primers were referenced form the study by Briolay et. al., 1998 (L15267 F:5'-GTT TGA TCC CGT TTC GTG TA-3'; H15891 R:5' -AAT GAC TTG AAG AAC CAC CGT-3; Gene bank Accession number: AY026411). Using Thermal Cycler device (BIO-RAD $\mathrm{T} 100^{\mathrm{TM}}$ ), target mtDNA cyt $\mathrm{b}$ gene site was amplified by optimizing the PCR conditions, concentrations of the chemicals, and annealing temperatures of the primers according to the study of Parmaksız and Şeker (2018). 2\% agarose gel was used in order to check the products occurring after PCR process. Agarose gel with addition of SYBR Green was placed in the tank with a content of $0.5 \mathrm{x}$ TBE solution, $4 \mu \mathrm{L}$ of PCR products and $4 \mu \mathrm{L}$ stain were loaded in the wells together, then were run at $120 \mathrm{~V}$ electricity currency for 25 minutes, and monitorized under UV light device. PCR products of target site were sent to a commercial company for sequence analysis with 3500 XL Genetic Analyzer (Thermo Fisher Scientific) device.

Raw data of mtDNA sequences were firstly converted in to FASTA format by evaluating with Chromas Pro v 2.0.1 (Technelysium Pty Ltd) and resulting sequences of all the samples were ranked utilizing BioEdit software version 7.2.5 program. The number of polymorphic sites and haplotypes, diversity of haplotypes and nucleotides, Tajima D and Fu's statistics for the populations were identified by using DNA SP5.10.01 program (Rozas et al., 2003). The phylogenetic relationship between haplotypes was identified via Network version 5.0 program.

\section{Results and Discussion}

\section{Genetic Variation}

From river systems of Euphrates and Tigris, variable sites and haplotypes were identified using sequence analysis of $586 \mathrm{bp}$ locus on mtDNA cyt b (Figure 2) for a total number of $65 C$. luteus samples. Variability of nucleotides by haplotypes from this gene site can be seen on Table 1 .

Mean nucleotide, Cytosine (C), Timin (T), Adenine (A), and Guanin $(\mathrm{G})$, content for all sequences was calculated as follows; $27.7 \%, 29 \%, 28.5 \%$, and $14.8 \%$, respectively.

13 polymorphic sites and 5 haplotypes were identified in a total number of 65 C. luteus samples collected from five diverse localities, variations of nucleotides by haplotype are shown on Table 1. Haplotype H1 was found in 54 samples and the most prevalent one. Haplotypes $\mathrm{H} 3, \mathrm{H} 4$, and $\mathrm{H} 5$ were identified in only one sample. 


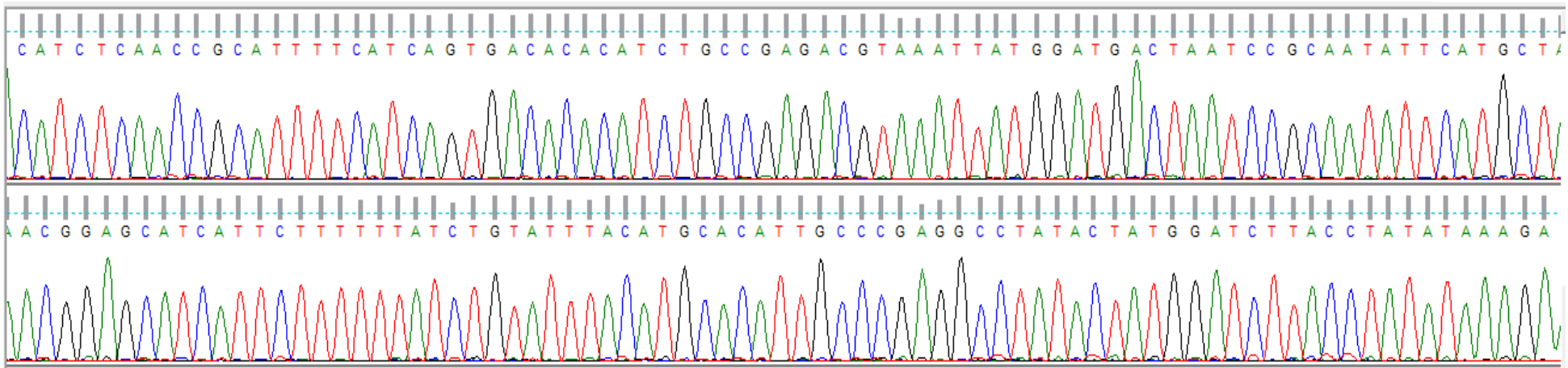

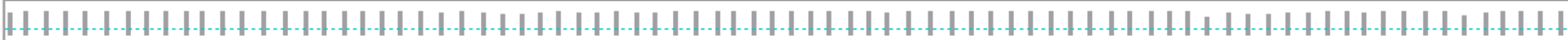
AACCTGAAACATCGGAGTAATCCTTTTACTACTAGTCATAATAACA GCTTTCGTCGGCTACGTCCTTCCATGAGGACAAA

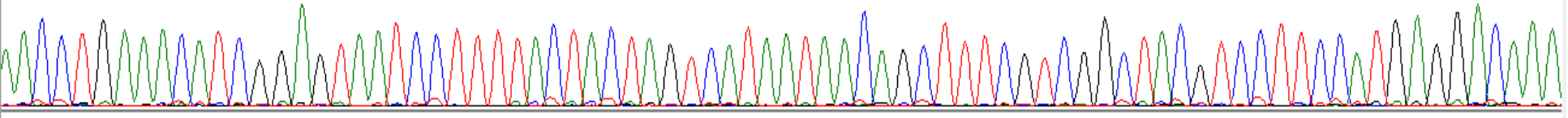

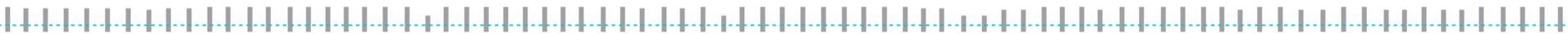

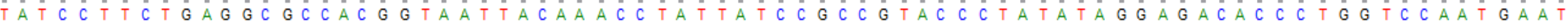

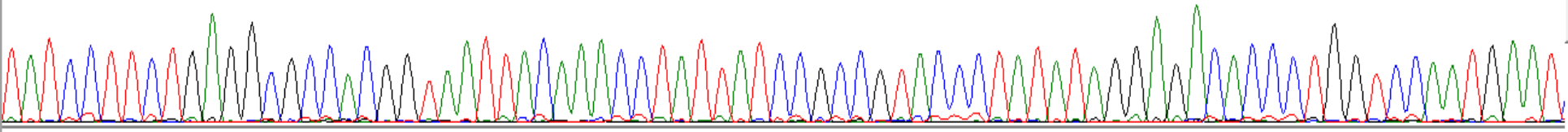

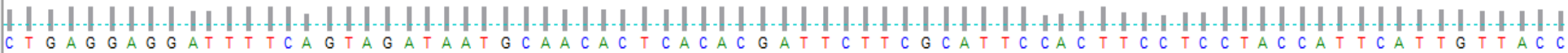

Figure 2. Chromatogram image of a sequence analysis from mtDNA cyt $b$ site

Table 1. Nucleotide diversity and haplotypes of cyt b locus

\begin{tabular}{|c|c|c|c|c|c|c|c|c|c|c|c|c|c|c|}
\hline \multirow[t]{2}{*}{ Haplotype } & \multicolumn{13}{|c|}{ Polymorphic Sites } & \multirow{2}{*}{$\begin{array}{c}\text { Accession } \\
\text { number }\end{array}$} \\
\hline & 117 & 174 & 303 & 324 & 345 & 408 & 424 & 444 & 456 & 474 & 493 & 537 & 541 & \\
\hline H1 (54 samples) & $\mathrm{T}$ & $\mathrm{G}$ & $\mathrm{T}$ & $\mathrm{A}$ & $\mathrm{C}$ & G & $\mathrm{T}$ & $\mathrm{A}$ & $\mathrm{G}$ & $\mathrm{A}$ & $\mathrm{G}$ & $\mathrm{C}$ & $\mathrm{G}$ & MW725236 \\
\hline H2 (8 samples) & $\mathrm{C}$ & $\mathrm{A}$ & $\mathrm{C}$ & $\mathrm{G}$ & $\mathrm{T}$ & . & . & $\mathrm{G}$ & $\mathrm{A}$ & $\mathrm{G}$ & . & $\mathrm{T}$ & $\mathrm{A}$ & MW725237 \\
\hline H3 (1 sample) & $\mathrm{C}$ & $\mathrm{A}$ & $\mathrm{C}$ & $\mathrm{G}$ & $\mathrm{T}$ & A & . & $\mathrm{G}$ & $\mathrm{A}$ & $\mathrm{G}$ & . & $\mathrm{T}$ & $\mathrm{A}$ & MW725238 \\
\hline H4 (1 sample) & . & 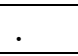 & & . & & . & $\mathrm{C}$ & . & . &. & . & . & & MW725239 \\
\hline H5 (1 sample) & $\mathrm{C}$ & $\mathrm{A}$ & $\mathrm{C}$ & $\mathrm{G}$ & $\mathrm{T}$ & . & . & . & . & $\mathrm{G}$ & $\mathrm{C}$ & . & & MW725240 \\
\hline
\end{tabular}

Table 2. Genetic diversity and neutrality tests of localities (N: number of samples, Nh: number of haplotypes, Hd: haplotype diversity, $\pi$ : nucleotide diversity)

\begin{tabular}{|l|l|l|c|c|c|c|c|}
\hline River System & Locality & \multicolumn{1}{|c|}{$\mathbf{N}$} & Nh and Haplotype distribution & Hd & $\boldsymbol{\pi}$ & Tajima's D & Fu's Fs \\
\hline Euphrates & Adiyaman & 16 & $\begin{array}{c}4(\mathrm{H} 1: 13) \\
(\mathrm{H} 2: 1) \\
(\mathrm{H} 3: 1) \\
(\mathrm{H} 5: 1)\end{array}$ & 0,350 & 0,00536 & $-0,51025$ & 2,810 \\
\hline Euphrates & Hilvan & 13 & $\begin{array}{c}2(\mathrm{H} 1: 11) \\
(\mathrm{H} 2: 2)\end{array}$ & 0,282 & 0,00481 & $-0,49831$ & 5,847 \\
\hline Euphrates & Birecik & 10 & $\begin{array}{c}2(\mathrm{H} 1: 7) \\
(\mathrm{H} 2: 3)\end{array}$ & 0,467 & 0,00796 & 1,41919 & 7,272 \\
\hline Tigris & Diyarbakır & 5 & $(\mathrm{H} 1: 5)$ & 0000 & 000000 & 0000000 & 0000 \\
\hline Tigris & Bismil & 21 & $\begin{array}{c}(\mathrm{H} 1: 18) \\
(\mathrm{H} 2: 2) \\
(\mathrm{H} 4: 1)\end{array}$ & 0,267 & 0,00325 & $-1,32016$ & 3,128 \\
\hline
\end{tabular}


As seen on Table 2, haplotype H1 was the only one which was seen in all localities. Haplotype $\mathrm{H} 2$, on the other hand, was commonly found in all other localities, except Diyarbakır. H3 and H5 were identified only in Adryaman, H4 only in Bismil locality. In Adıyaman, Hilvan, Birecik, Diyarbakır, and Bismil localities had; four, two, two and three different haplotypes respectively. The locality with the highest number in terms of both haplotype diversity and nucleotide diversity was Birecik, whereas Diyarbakır was the one with the lowest number. The results of Tajima's D and Fu's Fs neutrality tests were presented on Table 2 . Neutrality tests are used to determine whether populations have been selected in the past. The Tajima D test is mostly used to determine natural selection from DNA polymorphism. Neutrality tests are used to determine whether populations have been selected in the past. The Tajima D test is mostly used to detect natural selection from DNA polymorphism and the Fu's Fs test is used to determine population expansion. Tajima's D and Fu's Fs values were determined to be statistically insignificant ( $p>0.05$ ) for all localities.

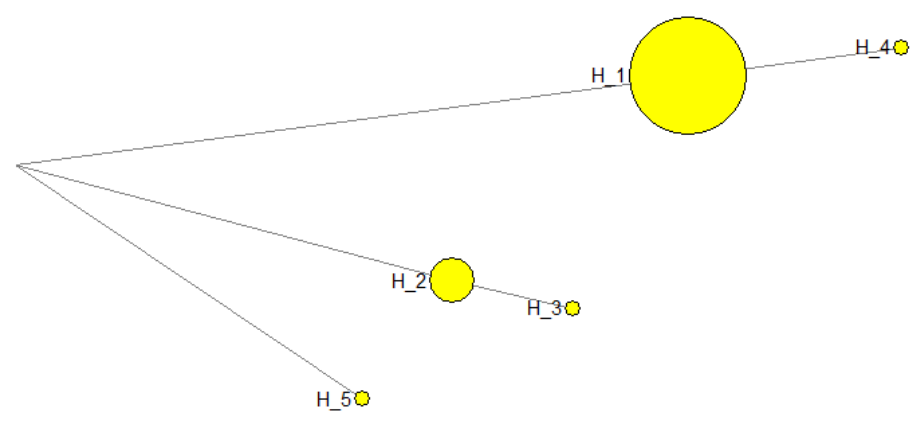

Figure 3. Median -Joining Network of haplotypes acquired after cyt $b$ sequence analysis

Figure 3 shows totally five haplotypes joined on Median-Joining Network created for 65 C. luteus samples, resulting network indicates an evolutionary connection. It is also possible to speculate that haplotypes $\mathrm{H} 2-\mathrm{H} 3$ and $\mathrm{H} 1-\mathrm{H} 4$ were connected, haplotype H5 was different from these.

Euphrates and Tigris Rivers have been undergoing considerable change as the result of human activities. Several dams were constructed on these rivers in order to obtain energy and to provide irrigation to agricultural lands and surrounding cities. Thus changes occurring the river bed resulted in dramatic changes for physical, chemical, and biological combination of river. In addition, environmental factors such as industrial factors, intensive fishery, and destruction of habitats would lead to extinction of numerous species or reduction of their populations (Ünlü et al., 1997). Conservation of population size and genetic variability is needed for survival of species. Decrease in the population size results in reduced genetic variability and poses a threat regarding survival chance of population.

It is also known that Carasius gibelio and $C$. auratus, which are invasive species in the localities where the samples were collected, has become dominant and has had a negative impact on native species (Parmaksiz et. al., 2017). As the result of observations, half of the fish caught in the nets of local fishermen were determined to be invasive species. This particularly puts a great pressure on the fish with economic importance. Because $C$. luteus is consumed by human, it is economically important, populations of this species are also influenced by this situation. Measurements should be taken in order to stop genetic loss of this species and to protect future of this species. To be able to apply an effective conservation program, there must be reliable genotypic data in the first place (Parmaksiz and Altundağ, 2018).

Valuable data were provided by Parmaksız and Eskici (2018) using mtDNA COI to evaluate genetic variation of $C$. luteus, by Parmaksiz (2020) using mtDNA D-loop sequences to enlighten genetic background of $C$. luteus. The use of multiple genetic marker systems increases the resolution power of genetic studies (Gruenthal et. al., 2007). The present study contributed to acquire further knowledge about genetic structure by analyzing cyt $b$ sequences either. Some studies have been carried out with this marker (cyt b) in different fish species collected from similar localities and haplotypes have been determined (Parmaksiz and Seker, 2018; Parmaksız and Altundag, 2018). For Arabibarbus grypus populations 5 polymorphic sites and 5 haplotypes were identified by Parmaksiz and Seker (2018). For Achantobrama marmid populations 4 polymorphic sites and 5 haplotypes were identified Parmaksiz and Altundag (2018).

In the present study 13 polymorphic sites and 5 haplotypes were identified following the assessment of cyt $b$ sequences of 65 samples collected from five localities in two different river systems. While haplotypes $\mathrm{H} 3, \mathrm{H} 4$, and $\mathrm{H} 5$ were observed in one each sample, haplotype H1 was established as the common haplotype which was seen in 54 samples and all localities. Total haplotype diversity (Hd) was 0.299; Nucleotide diversity $(\boldsymbol{\pi})$ was 0,00453 . Studies conducted in similar localities determined a total number of 7 haplotypes for D-loop locus, haplotype diversity (Hd) was 0.373 ; Nucleotide diversity $(\boldsymbol{\pi})$ was 0,00453 (Parmaks1z, 2020); for haplotype were identified for COI locus haplotype diversity (Hd) was 0.534 ; Nucleotide diversity $(\boldsymbol{\pi})$ was 0,00367 (Parmaksiz and Eskici, 2018). Results of the present study and other two surveys were in parallel. Haplotype and nucleotide diversity are im- 
portant indicators of genetic variation, as higher values indicate higher genetic variation (Falush et. al., 2003; Liu, 2017). Higher levels of genetic diversity reflect strong adaptation and survival abilities of populations (Barrett and Schluter, 2008). As seen, haplotype and nucleotide diversity of this fish species were found to be lower with respect to mtDNA markers.

\section{Conclusion}

It is crucial to take measurements to stop loss of genetic diversity and to start conservation studies. Firstly, invasive species should be controlled and excessive fishing must be prevented. In case of failure to take measurements, the level of genetic diversity will decrease further, feeding, reproduction, competition, and adaptation abilities of populations will decline too and target organism will be under threat of extinction.

\section{Compliance with Ethical Standard}

Conflict of interests: The authors declare that for this article they have no actual, potential or perceived conflict of interests.

Ethics committee approval: Ethics committee approval is not required.

Funding disclosure: This study was funded by Harran University Research Fund (Project No: 17217).

Acknowledgments: -

Disclosure: -

\section{References}

Aral, F., Doğu, Z., Şahinöz, E. (2014). Comparion of spermatological characteristics in Carasobarbus luteus (Heckel, 1843) and Carassius carassius living in Atatürk Dam Lake. Türk Tarım - Glda Bilim ve Teknoloji Dergisi, 2(4), 185-189. https://doi.org/10.24925/turjaf.v2i4.185-189.95

Barrett, R.D.H., Schluter, D. (2008). Adaptation from standing genetic variation. Trends in Ecology \& Evolution, 23(1), 38-44.

https://doi.org/10.1016/j.tree.2007.09.008

Bilici, S., Cicek, T., Ünlü, E. (2017). Observation on the age, growth and somatic condition of Carasobarbus luteus (Heckel, 1843) and Capoeta trutta (Heckel, 1843) (Cyprinidae) in the Tigris River, Turkey. Iranian Journal of Fisheries Sciences, 16(1), 170-187.
Briolay, J., Nicols Galtier, N., Brito, R. M., Bouvet, Y. (1998). Molecular Phylogeny of Cyprinidae Inferred from cytochrome b DNA Sequences. Molecular Phylogenetics and Evolution, 9(1), 100-108.

https://doi.org/10.1006/mpev.1997.0441

Coad, B. W. (2010). Freshwater Fishes of Iraq. Sofia-Moscow. Pensoft Publishers, 294 pp. ISBN: 978-954-642-530-0

Cognetti, G., Maltagliati, F. (2000). Biodiversity and adaptive mechanisms in brackish water fauna. Marine Pollution Bulletin, 40, 7-14.

https://doi.org/10.1016/S0025-326X(99)00173-3

Çelik, B., Saler, S. (2016). Atatürk baraj gölü'nde yaşayan bizir, Carasobarbus luteus (Heckel, 1843)'un sindirim sistemi içeriği. Journal of Limnology and Freshwater Fisheries Research, 2(2), 83-93.

https://doi.org/10.17216/LimnoFish-5000139495

Deng, Y., Song, N., Liu, M., Gao, T.X. (2014). Population genetic analysis of Perinereis aibuhitensis based on the mitochondrial DNA cyt b. Acta Hydrobiologica Sinica, 38(3), 597-601.

Fayazi, J., Moradi, M., Rahimi, G., Ashtyani, R., Galledari, H. (2006). Genetic differentiation and phylogenetic relationships among Barbus xanthopterus (Cyprinidae) populations in south west of Iran using mitochondrial DNA markers. Pakistan Journal of Biological Science, 9, 2249-2254. https://doi.org/10.3923/pjbs.2006.2249.2254

Falush, D., Stephens, M., Pritchard, J.K. (2003). Inference of population structure using multilocus genotype data: linked loci and correlated allele frequencies. Genetics, 164, 1567-1587.

https://doi.org/10.1093/genetics/164.4.1567

Frankham, R., Briscoe, D.A., Ballou, J.D. (2002). Introduction to Conservation Genetics. Cambridge University Press. ISBN: 9780511809002 https://doi.org/10.1017/CBO9780511808999

Goudie, A.S. (2018). Human Impact on the Natural Environment. Wiley-Blackwell, ISBN: 978-1-119-40355-5

Gökçek, K. Akyurt, I. (2008). Age and Growth Characteristics of Himri Barbel (Barbus luteus Heckel, 1843 in Orontes River, Turkey. Turkish Journal of Zoology, 32, 461-467. 
Gruenthal, K.M., Acheson, L.K., Burton, R.S. (2007). Genetic structure of natural populations of California red abalone (Haliotis rufescens) using multiple genetic markers. $M a$ rina Biology, 152, 1237-1248.

https://doi.org/10.1007/s00227-007-0771-4

Kuru, M. (1979). The fresh water fish of South-eastern Turkey-2 (Euphrates-Tigris sisteme). Hacettepe Bulletin of $\mathrm{Na}$ tural Sciences and Engineering, 7-8, 105-114.

Liu, Y., Li, C.H., Su, X.R., Wang, M.Q., Li, Y.Y., Li, Y. \& Li, T.W. (2013). Cloning and 254 characterization of hemerythrin gene from Sipuncula Phascolosoma esculenta. Genes \& Genomics, 35(1), 95-100.

https://doi.org/10.1007/s13258-013-0073-9

Liu, B.H. (2017). Statistical Genomics: Linkage, Mapping, and QTL Analysis. CRC Press. ISBN: 9780367400743

https://doi.org/10.1201/9780203738658

Maltagliati, F., D, G. G., Barbieri, M., Castelli, A., Dini, F. (2010). Phylogeography and genetic structure of the edible sea urchin Paracentrotus lividus (Echinodermata: Echinoidea) inferred from the mitochondrial cytochrome b gene. Biological Journal of the Linnean Society, 100(4), 910-923.

https://doi.org/10.1111/j.1095-8312.2010.01482.x

Manel, S., Guerin, P. E., Mouillot, D., Blanchet, S., Velez, L., Albouy, C., Pellissier, L. (2020). Global determinants of freshwater and marine fish genetic diversity. Nature Coтmunications, 11(1), 692.

https://doi.org/10.1038/s41467-020-14409-7

Mansoor, N.T., Al-Nasiri, F.S., Falah, A.B. (2020). New record of six species of Myxozoan parasites Myxobolus in Carasobarbus luteus from Tigris River at Baghdad city, Iraq. Tikrit Journal of Pure Science, 25(1), 42.

https://doi.org/10.25130/j.v25i1.932

Parmaksız, A., Oymak, S. A., Dogan, N., Naim, D. M., Unlu, E. (2017). Reproductive characteristics of an invasive species Carassius gibelio (Bloch, 1782) in Ataturk Dam Lake, Turkey. Indian Journal of Fisheries, 64(4), 2833

https://doi.org/10.21077/ijf.2017.64.4.67478-04

Parmaksız, A., Şeker, Ö. (2018). Genetic diversity of the endemic species Shabbout (Arabibarbus grypus (Heckel, 1843)) based on partial cytochrome b sequences of mitochondrial DNA. Aquatic Research, 1(3), 103-109.

https://doi.org/10.3153/AR18011
Parmaksı, A. ve Altundağ, A. (2018). Firat ve Dicle nehrinde yaşayan Achantobrama marmid (Heckel, 1843) popülasyonlarında genetik çeşitliliğin mtDNA cyt b gen dizileri kullanılarak belirlenmesi. Harran Üniversitesi Veteriner Fakültesi Dergisi, 7(1), 74-78.

https://doi.org/10.31196/huvfd.470797

Parmaksız, A., Eskici, H.K. (2018). Genetic variation of yellow barbell (Carasobarbus luteus (Heckel, 1843)) from four populations using mitochondrial DNA COI gene sequences. Applied Ecology and Environmental Research, 16(2), 1673-1682.

https://doi.org/10.15666/aeer/1602_16731682

Parmaksı, A. (2020). Population genetic diversity of yellow barbell (Carasobarbus luteus) from Kueik, Euphrates and Tigris Rivers based on mitochondrial DNA D-loop sequences. Turkish Journal of Fisheries and Aquatic Science, 20(1), 7986.

https://doi.org/10.4194/1303-2712-v20 108

Rahemo, Z. I., Al-Shatter, N.M. (2012). Observations on reproductive organs and tissues of two freshwater Cyprinid fishes. Trends in Fisheries Research, 1(2), 42-48.

Rozas, J., Sanchez- DelBarrio, J. C., Messeguer, X., Rozas, R. (2003). DnaSP DNA polymorphism analyses by the coalescent and other methods. Bioinformatics, 19, 24962497.

https://doi.org/10.1093/bioinformatics/btg359

Ryman, N. (1991). Conservation genetics considerations in fishery management. Journal of Fish Biology, 39, 211-224. https://doi.org/10.1111/j.1095-8649.1991.tb05085.x

Saraswat, D., Lakra, W.S., Nautiyal, P., Goswami, M., Shyamakant, K., Malakar, A. (2014). Genetic characterization of Clupisoma garua (Hamilton 1822) from six Indian populations using mtDNA cytochrome $\mathrm{b}$ gene. Mitochondrial DNA, 25(1), 70-77.

https://doi.org/10.3109/19401736.2013.782014

Spielman, D., Brook, B.W., Frankham, R., (2004). Most species are not driven to extinction before genetic factors impact them. Proceedings of The National Academy of Sciences of The United States of America, 101(42), 15261-15264. https://doi.org/10.1073/pnas.0403809101

Ünlü, E. (1991). A study on the biological characteristics of Capoeta trutta (Heckel, 1843) living in the Tigris River, Turkey. Turkish Journal of Zoology, 15, 22-38. 
Ünlü, E., Özbay, C., Kilic, A., Coskun, Y., Şeşen, R. (1997). GAP'ın faunaya etkileri. Türkiye Çevre Vakfi Yayını, $125,79-102$.

Ward, R.D. (2000). Genetics in fisheries management. Hydrobiologia, 420, 191-201.

https://doi.org/10.1023/A:1003928327503

Xia, L., Guo, B., Ye, Y., Li, J., Wu, C. (2016). Determination of genetic diversity of the cuttlefish Sepiella japonica in habiting Chinese coastal waters using the mitochondrial Dloop region: The valuable inspiration to artificial releasing Project. Biochemical Systematics and Ecology, 69, 274-282. https://doi.org/10.1016/j.bse.2016.05.015

Zhang, Q., Sun, C., Zhu, Y., Xu, N., Liu, H. (2020). Genetic diversity and structure of the round-tailed paradise fish (Macropodus ocellatus): Implications for population management. Global Ecology and Conservation, 21(2020), e00876. https://doi.org/10.1016/j.gecco.2019.e00876 